\title{
LIM Homeobox Transcription Factor 1 Beta
}

National Cancer Institute

\section{Source}

National Cancer Institute. LIM Homeobox Transcription Factor 1 Beta. NCI Thesaurus.

Code C75633.

LIM homeobox transcription factor 1 beta $(379 \mathrm{aa}, \sim 42 \mathrm{kDa}$ ) is encoded by the human LMX1B gene. This protein plays a role in limb development and transcription. 